\title{
Anabolic steroids purchased on the Internet as a cause of prolonged hypogonadotropic hypogonadism
}

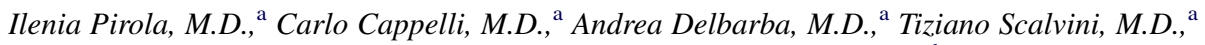 \\ Barbara Agosti, M.D., ${ }^{\mathrm{a}}$ Deodato Assanelli, M.D., ${ }^{\mathrm{a}}$ Antonio Bonetti, M.D., ${ }^{\mathrm{b}}$ and Maurizio Castellano, M.D. ${ }^{\mathrm{a}}$ \\ ${ }^{\text {a }}$ Internal Medicine and Endocrinology Unit, Department of Medical and Surgical Sciences, University of Brescia, Brescia; and \\ ${ }^{\mathrm{b}}$ Curriculum of Sports Science and Physical Exercise, Department of Clinical Science, University of Parma, Parma, Italy
}

\begin{abstract}
Objective: To report a case of hypogonadotropic hypogonadism due to the chronic abuse of anabolic steroids purchased over the Internet.

Design: Case report.

Setting: Endocrinology unit of the University of Brescia.

Patient(s): A 34-year-old man.

Intervention(s): A single dose (100 $\mu \mathrm{g}$ ) of triptorelin (triptorelin test).

Main Outcome Measure(s): Clinical symptoms, androgen normalization, levels of serum testosterone, folliclestimulating hormone, and luteinizing hormone.

Result(s): Within 1 month, the patient's serum testosterone was in the normal range, and he reported a return to normal energy and libido.

Conclusion(s): The World Anti-Doping Code has proved to be a very powerful and effective tool in the harmonization of antidoping efforts worldwide, but it is insufficient to combat this illegal phenomenon. To tackle the serious side effects caused by doping we believe that it is necessary to increase monitoring and adopt severe sanctions, particularly with regard to Internet sites. (Fertil Steril ${ }^{\circledR}$ 2010;94:2331.e1-e3. C2010 by American Society for Reproductive Medicine.)
\end{abstract}

Key Words: Anabolic steroids, doping, hypogonadotropic hypogonadism, triptorelin

Doping involves the use of artificial means or substances with the specific aim of improving performance, despite well-known adverse effects on health (1). This practice has spread to the general population, in particular to young adults, along with the exaggerated ideals of body image portrayed by the mass media (2-4). Over the last few years, Internet marketing may have played an important role in increasing consumption of anabolic drugs such as anabolic androgen steroids (AAS) and clomiphene citrate (5). We describe the case of a young male with prolonged hypogonadotropic hypogonadism due to ongoing consumption of various doping drugs purchased over the Internet, where they are readily available.

\section{CASE REPORT}

A 34-year-old man presented to our department in September 2008 for loss of libido and energy and for mild depression. He was

Received February 10, 2010; revised March 13, 2010; accepted March 17, 2010; published online April 22, 2010.

I.P. has nothing to disclose. C.C. has nothing to disclose. A.D. has nothing to disclose. T.S. has nothing to disclose. B.A. has nothing to disclose. D.A. has nothing to disclose. A.B. has nothing to disclose. M.C. has nothing to disclose.

Reprint requests: Carlo Cappelli, M.D., Department of Medical and Surgical Sciences, Internal Medicine and Endocrinology Unit, University of Brescia, c/o $2^{\wedge}$ Medicina Spedali Civili di Brescia, Piazzale Spedali Civili no. 1, 25100 Brescia, Italy (FAX: +390303388147; E-mail: cappelli@ med.unibs.it). a computer programmer and a nonprofessional bodybuilder with an unremarkable personal medical history. He admitted to having used doping drugs since he was 21 years old. More specifically, he would perform cycles of intramuscular injections of nandrolone $(25 \mathrm{mg})$ and stanazol $(25 \mathrm{mg})$ daily for 8 weeks, followed by mesterolone ( $50 \mathrm{mg} /$ day) for 15 days. Then he would then take clomiphene citrate $(50 \mathrm{mg} /$ day $)$ for 1 week, followed by an injection of human chorionic gonadotropin (2,000 IU) three times in 1 week. He had repeated these cycles from 1995 to 2005 . From 2005 to August 2008, to his nandrolone and stanazol cycle he added an intramuscular injection of boldenone $(50 \mathrm{mg})$ daily for 3 weeks. He said he had bought all the drugs on the Internet.

The patient was $175 \mathrm{~cm}$ tall and $80 \mathrm{~kg}$, and he appeared very muscular and toned. His blood pressure and pulse rate were normal. Examination of his heart, lungs, and abdomen were likewise unremarkable. The physical examination showed normal secondary sexual characteristics, but the genital examination revealed bilateral testicular atrophy (volume $2.9 \mathrm{~mL}$ and weak consistence). Despite his testicular atrophy, the semen analysis revealed a normal count $\left(79 \times \times 10^{6}\right.$ spermatozoa/mlmL $)$ and mild morphology derangements (between $46 \%$ and $58 \%$ ). The blood count and chemistry were normal, but his level of creatine kinase was $454 \mathrm{IU} / \mathrm{L}$ (normal range: 20-170 IU/L), alanine aminotransferase $61 \mathrm{IU} / \mathrm{L}$ (normal range: 5-50 IU/L), and aspartate aminotransferase 23 IU/L (normal range: 5-50 IU/L). The endocrinologic investigations are reported in Table 1. 


\begin{tabular}{|c|c|c|c|}
\hline \multicolumn{4}{|c|}{$\begin{array}{l}\text { Serum hormone profile in a man with hypogonadotropic } \\
\text { hypogonadism due to the chronic abuse of anabolic } \\
\text { steroids. }\end{array}$} \\
\hline Hormone & $\begin{array}{c}\text { September } \\
2008\end{array}$ & $\begin{array}{c}\text { February } \\
2009\end{array}$ & $\begin{array}{c}\text { Normal } \\
\text { range }\end{array}$ \\
\hline $\mathrm{FSH}(\mathrm{mlU} / \mathrm{mL})$ & 1 & 2 & $1.5-13.0$ \\
\hline LH (mlU/mL) & $<0.5$ & 2 & $1-8$ \\
\hline $\mathrm{HGH}(\mathrm{ng} / \mathrm{mL})$ & $<0.1$ & $<0.1$ & $<0.4$ \\
\hline IGF (ng/mL) & 241 & - & $109-307$ \\
\hline $\mathrm{TSH}(\mathrm{mlU} / \mathrm{L})$ & 1.249 & 1.345 & $0.270-4.200$ \\
\hline $\mathrm{FT}_{4}(\mathrm{pg} / \mathrm{mL})$ & 7.9 & - & $7-18$ \\
\hline DHEAS $(\mathrm{pg} / \mathrm{mL})$ & 2.2 & - & $0.80-5.60$ \\
\hline $\mathrm{E}_{2}(\mathrm{pg} / \mathrm{mL})$ & $<10$ & - & $11-45$ \\
\hline $\mathrm{T}(\mathrm{ng} / \mathrm{mL})$ & 0.3 & 1.7 & $2.7-10$ \\
\hline $\mathrm{PRL}(\mathrm{ng} / \mathrm{mL})$ & 14.7 & 13.5 & $3.0-23$ \\
\hline SHBG (nmol/L) & 8 & 21 & $13-71$ \\
\hline \multicolumn{4}{|c|}{$\begin{array}{l}\text { Note: } \mathrm{DHEAS}=\text { dehydroepiandrosterone sulfate; } \mathrm{E}_{2}=\text { estradiol; } \mathrm{FSH}= \\
\text { follicle-stimulating hormone; } \mathrm{fT} 4=\text { free thyroxine; } \mathrm{HGH}=\text { human } \\
\text { growth hormone; IGF = insulin-like growth factor; } \mathrm{LH}=\text { luteinizing } \\
\text { hormone; } \mathrm{PRL}=\text { prolactin; } \mathrm{SHBG}=\text { sex hormone-binding globulin; } \\
\mathrm{T}=\text { testosterone; } \mathrm{TSH}=\text { thyroid-stimulating hormone. }\end{array}$} \\
\hline \multicolumn{4}{|c|}{ Pirola. Anabolic steroids online. Fertil Steril 2010.} \\
\hline
\end{tabular}

In February 2009, the patient continued to report loss of libido and great tiredness. A second physical examination was performed. His levels of alanine transferase and creatine kinase were all within the normal range, but the endocrinologic investigations were still abnormal with the exception of sex hormone-binding globulin level (see Table 1). Because the situation had persisted for months after ASS withdrawal, we administered a single dose $(100 \mu \mathrm{g})$ of triptorelin (triptorelin test), which showed a normal response (Fig. 1). Ten days after the triptorelin test, the patient reported a great amelioration of energy, and his serum testosterone was $7.0 \mathrm{ng} / \mathrm{mL}$. One month later, his serum testosterone was within the normal range, and he reported a return to normal libido and energy.

\section{DISCUSSION}

Despite the perception that doping is a modern phenomenon, there are many examples of substance use by ancient civilizations, including extracts derived from plants or animals. Historically, the use of drugs in sports can be traced back to 776 B.C. One of the earliest reports describes the use of a diet of dried figs to improve the performance of Charmis, the Spartan winner of the stadium race at the Olympic Games of 668 B.C. (6). Later, Roman gladiators also used unspecified stimulants to overcome fatigue and injury (7). Amphetamines, the first "effective" performance-enhancing drugs, crossed over into sports in the early 1950s. These drugs, nicknamed la bomba by Italian cyclists, minimize the uncomfortable sensations of fatigue during exercise (8). Since then, many other substances have been used to improve athletic performance.

Epidemiologic data on the use and abuse of doping drugs are notoriously difficult to obtain because the drugs are illegal. Nevertheless, the use of these substances appears to have become widespread, ranging from the domain of elite athletics to the general community in many countries $(5,9-12)$. The popularity of doping drugs seems to be due to the large diffusion of print media, sports and bodybuilding magazines, advertisements, and television (5). Our patient reported over a decade of chronic consumption of
FIGURE 1

Triptorelin test showing a normal response.

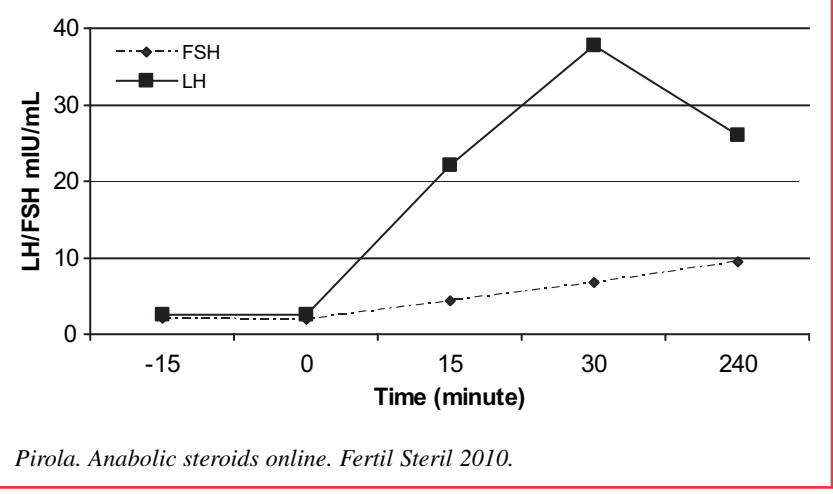

a cocktail of doping drugs, mainly androgens, which caused his prolonged hypogonadotropic hypogonadism; all were purchased on Internet sites.

The side effects of the use and abuse of high doses of anabolic steroids have been well documented. After the first report, a fatal heatstroke in a cyclist in 1967 after abuse of amphetamines (8), many other reports have described the side effects of doping drugs (1319). Because they derive from testosterone, anabolic steroids have pronounced effects on the male pituitary gonadal axis, affecting the regulation of production of serum luteinizing hormone (LH) and follicle-stimulating hormone and inducing a state of hypogonadotropic hypogonadism characterized by decreased serum endogenous testosterone production and impaired spermatogenesis, often reversible with withdrawal of the drugs (19). Another consequence of ASS abuse is the reduction of sex hormone-binding globulin, which will continue long after ASS withdrawal (20).

Our patient showed no spermatogenesis dysfunction, even though he had used anabolic steroids for over a decade. This could be explained by his periodic self-administered treatment with clomiphene citrate and human chorionic gonadotropin between the cycles of steroids. Clomiphene is a selective estrogen receptor modulator that blocks the feedback inhibition of estradiol at the level of the hypothalamus, thus increasing pituitary release of both LH and folliclestimulating hormone $(5,21)$. In addition, clomiphene decreases the conversion of androgen substrate to estrogen by aromatase inhibition (22). It is this ability to block estrogen that leads to its postcycle use by bodybuilders to reduce the development of gynecomastia after self-administration of androgen drugs. Clomiphene is extensively used in the induction of ovulation (23), but it has also been used to reverse hypogonadotropic hypogonadism in many conditions like falciform anemia, uremia, and alcohol abuse, and it stimulates gonadotropin secretion in patients with sulpiride-induced hyperprolactinemia and gonadotropin suppression (24).

Moreover, clomiphene and LH (LH-RH) have been successfully used to treat severe hypothalamic-pituitary dysfunction due to anabolic steroid abuse. Van Breda et al. (17) reported that supraphysiologic doses of LH-RH restored normal pituitary-testicular axis interplay, and Tan et al. (25) used prolonged clomiphene citrate treatment to cure symptomatic hypogonadism in bodybuilders. The cycles of pituitary stimuli with clomiphene and human chorionic gonadotropin could also explain why our patient did not exhibit the hypothalamic-pituitary dysfunction that had been clinically evident previously. 
The most important information relevant to the present case, in our opinion, is the apparent ease with which one can purchase these substances on the Internet. Indeed, very recently, Melnik (5) condemned the "role of the World Wide Web" in illegal drug marketing, reporting more than 47,500 new steroid-related cases in 2006, for an increase of $400 \%$ since their debut in 2002 (26). Many online bodybuilding stores also give information on the use and combination of drugs, their dosages, and their side effects. We have personally purchased stanazol, nandrolone, and other doping drugs online, confirming how easy it is to obtain these drugs over the Internet. Even though it has been largely demonstrated that more than 50\% of illicit androgens are made available to the fitness community by licensed health-care providers (5), in our opinion the Internet may have played an important role in the increasing consumption of anabolic drugs, especially among young people. Population studies have documented widespread androgen abuse among students all over the world in places such as South Africa, the United Kingdom, Scandinavia, and Australia (27, 28). Moreover, a recent investigation of Polish adolescents revealed doping drugs abuse by $6.2 \%$ of young men and $2.9 \%$ of women (11).

Although the World Anti-Doping Code, adopted in 2003 and effective as of 2004, has proved to be a very powerful and effective tool in the harmonization of antidoping efforts worldwide, it has not been sufficient to tackle this illegal phenomenon. For this reason, we believe that it is necessary to increase monitoring and adopt more severe sanctions, particularly with regard to Internet sites.

\section{REFERENCES}

1. Lippi G, Banfi G, Franchini M, Guidi GC. New strategies for doping control. J Sports Sci 2008;26: 441-5.

2. Kanayama G, Gruber AJ, Pope HG Jr, Borowiecki JJ, Hudson JI. Over-the-counter drug use in gymnasiums: an underrecognized substance abuse problem? Psychother Psychosom 2001;70:137-40.

3. Kanayama G, Pope HG, Cohane G, Hudson JI. Risk factors for anabolic-androgenic steroid use among weightlifters: a case-control study. Drug Alcohol Depend 2003;71:77-86.

4. Komoroski EM, Rickert VI. Adolescent body image and attitudes to anabolic steroid use. Am J Dis Child 1992;146:823-8.

5. Melnik BC. Androgen abuse in the community. Curr Opin Endocrinol Diabetes Obes 2009;16:218-23.

6. Yesalis CE, Bahrke MS, History of doping in sport. In: Performance-enhancing substances in sport and exercise. 1st ed. Champaign, Illinois: Eds Human Kinetics, 2002:1-20.

7. Voy RO, Deeter K. Drugs, sport, and politics. Champaign, Illinois: Leisure Press, 1991:227.

8. Noakes TD. Tainted glory-doping and athletic performance. N Engl J Med 2004;351:847-9.

9. Skårberg K, Nyberg F, Engström I. The development of multiple drug use among anabolic-androgenic steroid users: six subjective case reports. Subst Abuse Treat Prev Policy 2008;3:24.

10. Yesalis CE, Bahrke MS. Anabolic-androgenic steroids: current issues. Sports Med 1995;19:326-40.

11. Rachoń D, Pokrywka L, Suchecka-Rachoń K. Prevalence and risk factors of anabolic-androgenic steroids (AAS) abuse among adolescents and young adults in Poland. Soz Praventivmed 2006;51:392-8.
12. Nilsson S, Baigi A, Marklund B, Fridlund B. The prevalence of the use of androgenic anabolic steroids by adolescents in a county of Sweden. Eur J Public Health 2001;11:195-7.

13. Quaglio G, Fornasiero A, Mezzelani P, Moreschini S, Lugoboni F, Lechi A. Anabolic steroids: dependence and complications of chronic use. Intern Emerg Med 2009;4:289-96.

14. Bonetti A, Tirelli F, Catapano A, Dazzi D, Dei Cas A, Solito F, et al. Side effects of anabolic androgenic steroids abuse. Int J Sports Med 2008;29:679-87.

15. Pagonis TA, Angelopoulos NV, Koukoulis GN, Hadjichristodoulou CS. Psychiatric side effects induced by supraphysiological doses of combinations of anabolic steroids correlate to the severity of abuse. Eur Psychiatry 2006;21:551-62.

16. Hassan NA, Salem MF, Sayed MA. Doping and effects of anabolic androgenic steroids on the heart: histological, ultrastructural, and echocardiographic assessment in strength athletes. Hum Exp Toxicol 2009;28:273-83.

17. van Breda E, Keizer HA, Kuipers $H$, Wolffenbuttel BH. Androgenic anabolic steroid use and severe hypothalamic-pituitary dysfunction: a case study. Int J Sports Med 2003;24:195-6.

18. La Rosée K, Schulz A, Böhm M, Erdmann E. Acute cardiac failure in a bodybuilder. Dtsch med Wochenschr 1997;122:1586-90.

19. Boyadjiev NP, Georgieva KN, Massaldjieva RI, Gueorguiev SI. Reversible hypogonadism and azoospermia as a result of anabolic-androgenic steroid use in a bodybuilder with personality disorder: a case report. J Sports Med Phys Fitness 2000;40: 271-4.
20. Graham MR, Grace FM, Boobier W, Hullin D, Kicman A, Cowan D, et al. Homocysteine induced cardiovascular events: a consequence of long term anabolic androgenic steroid (AAS) abuse. Br J Sports Med 2006;40:644-8.

21. Taylor F, Levine L. Clomiphene citrate and testosterone gel replacement therapy for male hypogonadism: efficacy and treatment costs. J Sex Med 2010;7: 269-76.

22. Casper RF. Aromatase inibhitors in ovarian stimulation. J Steroid Biochem Mol Biol 2007;106:71-5.

23. Palomba S, Pasquali R, Orio F Jr, Nestler JE. Clomiphene citrate, metformin or both as first-step approach in treating anovulatory infertility in patients with polycystic ovary syndrome (PCOS): a systematic review of head-to-head randomized controlled studies and meta-analysis. Clin Endocrinol 2009;70: 311-21.

24. Bjork JTT, Varma RR, Borkowf HI. Clomiphene citrate therapy in a patient with Laennec's cirrhosis. Gastroenterology 1977;72:1308-11.

25. Tan RS, Vasudevan D. Use of clomiphene citrate to reverse premature andropause secondary to steroid abuse. Fertil Steril 2003;79:203-5.

26. Wood RI. Anabolic-androgenic steroid dependence? Insights from animals and humans. Front Neuroendocrinol 2008;29:490-506.

27. Nilsson S. Androgenic anabolic steroid use among male adolescents in Falkenberg. Eur J Clin Pharmacol 1995;48:9-11.

28. Handelsman DJ, Gupta L. Prevalence and risk factors for anabolic-androgenic steroid abuse in Australian high school students. Int J Androl 1997;20: 159-64. 